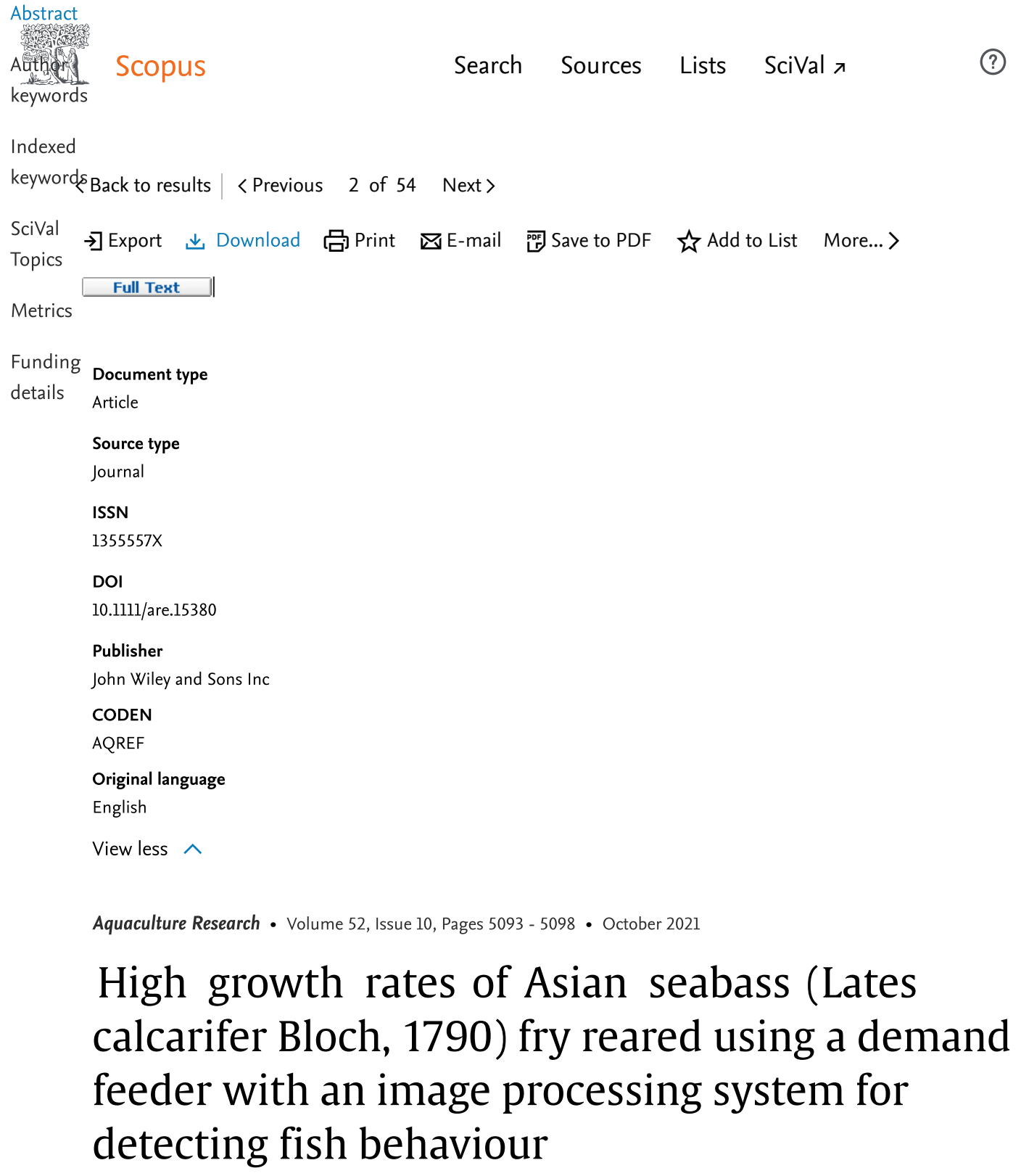

Indexe

keyword $\delta$ Back to results $\mid$ Previous 2 of 54 Next >

SciVal

Topics

Metrics

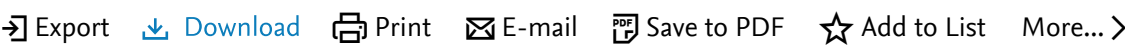

Document type

Article

Source type

Journal

ISSN

1355557X

DOI

10.1111/are.15380

Publisher

John Wiley and Sons Inc

CODEN

AQREF

Original language

English

View less $ヘ$

Aquaculture Research • Volume 52, Issue 10, Pages 5093 - 5098 • October 2021

\section{High growth rates of Asian seabass (Lates calcarifer Bloch, 1790) fry reared using a demand feeder with an image processing system for detecting fish behaviour}

Cited by 0 documents

Inform me when this document is cited in Scopus:

Set citation alert >

Related documents

Demand feeding system using an infrared light sensor for Brownmarbled grouper juveniles, Epinephelus fuscoguttatus

Mukai, Y. , Tan, N.H. , Rosli, M.K. (2016) Sains Malaysiana

Dualistic feeding pattern of Nile tilapia (Oreochromis niloticus, L.) reared under different selffeeding system conditions

Pratiwy, F.M. , Kohbara, J. (2018) Aquaculture Research

Combined effect of photoperiod and self-feeder on the growth performance of striped knifejaw, Oplegnathus fasciatus

Biswas, A. , Takaoka, O. , Kumai, $\mathrm{H}$.

(2016) Aquaculture

View all related documents based on references

Find more related documents in Scopus based on:

Authors > Keywords >

Mukai Y. ${ }^{a}$, Taha Z. ${ }^{b}, \quad$ Ismail K.M. ${ }^{c}, \quad$ Tan N.H. ${ }^{c}$, Mohd Razman M.A. ${ }^{d}, \quad$ Mat Jizat J.A. ${ }^{d}$

国 Save all to author list

a Department of Marine Science, Kulliyyah of Science, International Islamic University Malaysia, Kuantan, Malaysia

b Dzuki Consultancy and Training. DR67, Kampung Kuala Pahang, Pekan, Malaysia

${ }^{c}$ Department of Biotechnology, Kulliyyah of Science, International Islamic University Malaysia, Kuantan, Malaysia

d Innovative Manufacturing, Mechatronics \& Sports Laboratory, Faculty of Manufacturing Engineering, Universiti Malaysia Pahang (Pekan Campus), Pekan, Malaysia

Full text options $\vee$

\title{
Abstract
}

The feeding behaviour and growth rates of Asian seabass (Lates calcarifer Bloch, 1790) fry were studied using a new type demand (NTD) feeder. This feeding system was equipped with a programme to detect hunger behaviour in fish and automatically dispense pellets. This system could overcome hierarchy in fish during feeding. Fish rearing experiments were conducted to compare the NTD feeder with infrared light demand (ILD) and automatic timer (AT) feeders. The specific growth rate of body weight $\left(\mathrm{SGR}_{\mathrm{BW}}\right)$ was significantly higher with the use of the NTD feeder than with the ILD or AT feeders. The specific growth rate of total length $\left(\mathrm{SGR}_{\mathrm{TL}}\right)$ and feed conversion ratios (FCR) showed no significant differences among the three types of feeders. Fish feeding behaviour experiments were conducted, and the feeding frequencies were compared. The average feeding frequency and feeding amount per day by the NTD feeder were significantly higher than those by the ILD feeder. In the NTD 
feeder, seabass ate small amounts of pellets with high frequencies at each feeding time. Therefore, high frequency feeding could be one of the reasons for the high growth rates of fish fed using the NTD feeder. (C) 2021 John Wiley \& Sons Ltd

Abstract

Author

Author keywords

keywords

fish behaviour; images processing system; new type demand feeder; specific growth rates

Indexed

keywords

SciVal

Indexed keywords

SciVal Topics (i)

Metrics

Metrics

Funding Funding details

details

References (24)

View in search results format $>$

All

Export 吕Print 局E-mail 品 Save to PDF Create bibliography

1 Alanärä, A.

The use of self-feeders in rainbow trout (Oncorhynchus mykiss) production

(1996) Aquaculture, 145 (1-4), pp. 1-20. Cited 74 times.

doi: 10.1016/S0044-8486(96)01346-4

View at Publisher

2 Alanärä, A., Brännäs, E.

A test of the individual feeding activity and food size preference in rainbow trout using demand feeders

(1993) Aquaculture International, l (1), pp. 47-54. Cited 33 times. doi: $10.1007 / B F 00692663$

View at Publisher

3 Amano, M., ligo, M., Sunuma, T., Yamashita, M., Furukawa, K., Tabata, M., Yamamori, $\mathrm{K}$.

Development of new self-feeding system for mass rearing of ayu Plecoglossus altivelis altivelis under artificial and natural light-dark cycles

(2007) Fisheries Science, 73 (4), pp. 800-807. Cited 7 times.

doi: $10.1111 / j .1444-2906.2007 .01399 . x$

View at Publisher

4 Azzaydi, M., Madrid, J.A., Zamora, S., Sánchez-Vázquez, F.J., Martínez, F.J.

Effect of three feeding strategies (automatic, ad libitum demand-feeding and time-restricted demand-feeding) on feeding rhythms and growth in European sea bass (Dicentrarchus labrax L.)

(1998) Aquaculture, 163 (3-4), pp. 285-296. Cited 105 times. doi: $10.1016 / 50044-8486(98) 00238-5$

View at Publisher 
5 Boujard, T., Leatherland, J.F.

Circadian rhythms and feeding time in fishes

(1992) Environmental Biology of Fishes, 35 (2), pp. 109-131. Cited 253 times. doi: $10.1007 / B F 00002186$

View at Publisher

6 Brännäs, E., Alanärä, A.

Effect of reward level on individual variability in demand feeding activity and growth rate in Arctic charr and rainbow trout

(1994) Journal of Fish Biology, 45 (3), pp. 423-434. Cited 49 times. doi: $10.1111 / j .1095-8649.1994 . t b 01325 . x$

View at Publisher

7 Covès, D., Beauchaud, M., Attia, J., Dutto, G., Bouchut, C., Bégout, M.L. Long-term monitoring of individual fish triggering activity on a self-feeding system: An example using European sea bass (Dicentrarchus labrax) (Open Access)

(2006) Aquaculture, 253 (1-4), pp. 385-392. Cited 41 times.

doi: $10.1016 /$ j.aquaculture.2005.08.015

View at Publisher

8 Flood, M.J., Noble, C., Kagaya, R., Damsgård, B., Purser, G.J., Tabata, M.

Examining the daily feeding rhythms of amago Oncorhynchus masou masou using self-feeding systems

(2011) Aquaculture, 318 (1-2), pp. 244-247. Cited 5 times. doi: 10.1016/j.aquaculture.2011.05.007

View at Publisher

9 Fortes-Silva, R., Costa, L.S., Paulino, R.R., Rodrigues, E.J.D., Sanchez-Vazquez, F.J., Rosa, P.V.

Hybrid fish model (Pseudoplatystoma reticulatum $Q \times$ Leiarius marmoratus $\left.{ }^{\lambda}\right)$ to study feeding behaviour: protein source self-selection and demand-feeding rhythms

(2017) Aquaculture Research, 48 (7), pp. 3705-3718. Cited 7 times. http://onlinelibrary.wiley.com/journal/10.1111/(ISSN) $1365-2109$ doi: $10.1111 /$ are.13196

View at Publisher

10 Kohbara, J., Hidaka, I., Kuriyama, I., Yamashita, M., Ichikawa, M., Furukawa, K., Aida, K., (...), Tabata, M.

Nocturnal/diurnal demand-feeding pattern of yellowtail Seriola quinqueradiata under different keeping conditions

(2000) Fisheries Science, 66 (5), pp. 955-962. Cited 23 times. doi: $10.1046 / j .1444-2906.2000 .00152 . x$

View at Publisher

11 Kohbara, J., Hidaka, I., Matsuoka, F., Osada, T., Furukawa, K., Yamashita, M., Tabata, M.

Self-feeding behavior of yellowtail, Seriola quinqueradiata, in net cages: Diel and seasonal patterns and influences of environmental factors 
12 Kohbara, J., Hidaka, I., Yamashita, M., Ichikawa, M., Furukawa, K., Aidaand, K., Tabata, M.

Effect of reward level on the number of food demands in yellowtail Seriola quinqueradiata

(2001) Fisheries Science, 67 (4), pp. 660-666. Cited 16 times. doi: 10.1046/j.1444-2906.2001.00303.x

View at Publisher

13 Mukai, Y., Tan, N.H., Rosli, M.K., Liau, C.F.

Demand feeding system using an infrared light sensor for Brown-marbled grouper juveniles, Epinephelus fuscoguttatus

(2016) Sains Malaysiana, 45 (5), pp. 729-733. Cited 7 times. http://www.ukm.my/jsm/pdf_files/SM-PDF-45-52016/08\%20Yukinori\%20Mukai.pdf

14 Navarro, D.B., Rubio, V.C., Luz, R.K., Madrid, J.A., Sánchez-Vázquez, F.J. Daily feeding rhythms of Senegalese sole under laboratory and farming conditions using self-feeding systems

(2009) Aquaculture, 291 (1-2), pp. 130-135. Cited 31 times. doi: 10.1016/j.aquaculture.2009.02.039

View at Publisher

15 Nickum, J.G.C., Bart, H.L., Bowser, J.P.R., Greer, I.E., Hubbs, C., Jenkins, J.A., MacMillan, J.R., (...), Tomasso, J.R.

(2004) Guidelines for the Use of Fishes in Research. Cited 260 times.

Published by, American Fisheries Society

16 Paspatis, M., Boujard, T.

A comparative study of automatic feeding and self-feeding in juvenile Atlantic salmon (Salmo salar) fed diets of different energy levels

(1996) Aquaculture, 145 (1-4), pp. 245-257. Cited 71 times. doi: 10.1016/S0044-8486(96)01336-1

View at Publisher

17 Razman, M.A.M., Susto, G.A., Cenedese, A., Abdul Majeed, A.P.P., Musa, R.M., Abdul Ghani, A.S., Adnan, F.A., (...), Mukai, Y.

Hunger classification of Lates calcarifer by means of an automated feeder and image processing

(2019) Computers and Electronics in Agriculture, 163, art. no. 104883. Cited 13 times.

www.elsevier.com/inca/publications/store/5/0/3/3/0/4

doi: 10.1016/j.compag.2019.104883

View at Publisher

18 Razman, M.A.M., Susto, G.A., Cenedese, A., Abdul Majeed, A.P.P., Musa, R.M., Abdul Ghani, A.S., Adnan, F.A., (...), Mukai, Y.

(2020) Applied Sciences and Technology. Hunger Classification of Lates calcarifer, p. 60.

(p., Springer

https://doi.org/10.1007/978-981-15-2237-6 
19 da Silva Reis, Y., Leite, J.L.R., de Almeida, C.A.L., Pereira, D.S.P., Vidal, L.V.O., de Araujo, F.G., Fortes-Silva, R.

New insights into tambaqui (Colossoma macropomum) feeding behavior and digestive physiology by the self-feeding approach: effects on growth, dial patterns of food digestibility, amylase activity and gastrointestinal transit time

(2019) Aquaculture, 498, pp. 116-122. Cited 8 times.

http://www.journals.elsevier.com/aquaculture/

doi: 10.1016/j.aquaculture.2018.08.054

View at Publisher

20 Sánchez-Vázquez, F.J., Tabata, M.

Circadian rhythms of demand-feeding and locomotor activity in rainbow trout

(1998) Journal of Fish Biology, 52 (2), pp. 255-267. Cited 89 times.

doi: 10.1006/jfbi.1997.0576

View at Publisher

21 Shima, T., Yamamoto, T., Furuita, H., Suzuki, N.

Effect of the response interval of self-feeders on the selfregulation of feed demand by rainbow trout (Oncorhynchus mykiss) fry

(2003) Aquaculture, 224 (1-4), pp. 181-191. Cited 9 times.

http://www.journals.elsevier.com/aquaculture/

doi: 10.1016/S0044-8486(03)00219-9

View at Publisher

22 Sunuma, T., Amano, M., Yamanome, T., Furukawa, K., Yamamori, K.

Self-feeding activity of a pleuronectiform fish, the barfin flounder

(2007) Aquaculture, 270 (1-4), pp. 566-569. Cited 22 times.

doi: 10.1016/j.aquaculture.2007.04.083

View at Publisher

23 Taha, Z., Razman, M.A.M., Abdul Ghani, A.S., Abdul Majeed, A.P.P., Musa, R.M., Adnan, F.A., Sallehudin, M.F., (...), Mukai, Y.

The classification of hunger behaviour of Lates Calcarifer through the integration of image processing technique and kNearest Neighbour learning algorithm (Open Access)

(2018) IOP Conference Series: Materials Science and Engineering, 342 (1), art. no. 012017 . Cited 4 times.

http://www.iop.org/E)/journal/mse

doi: 10.1088/1757-899X/342/1/012017

View at Publisher

24 Taha, Z., Razman, M.A.M., Adnan, F.A., Abdul Ghani, A.S., Abdul Majeed, A.P.P., Musa, R.M., Sallehudin, M.F., (...), Mukai, Y.

The Identification of Hunger Behaviour of Lates Calcarifer through the Integration of Image Processing Technique and Support Vector Machine (Open Access)

(2018) IOP Conference Series: Materials Science and Engineering, 319 (1), art. no. 012028 . Cited 17 times.

http://www.iop.org/E)/journal/mse

doi: $10.1088 / 1757-899 \times / 319 / 1 / 012028$

View at Publisher 
Abstract

Author

keysdodout Scopus

Language

日本語に切り替える

切换到简体中文

切換到繁體中文

Русский язык

\section{Customer Service}

Help

Contact us

keywords

Scilsciopus blog

Topseopus API

Privacy matters
Metrics

Funding

details

ELSEVIER

Terms and conditions $\pi \quad$ Privacy policy $\pi$

Copyright $\left(\right.$ C) Elsevier B.V ז. All rights reserved. Scopus ${ }^{\circledR}$ is a registered trademark of Elsevier B.V.

We use cookies to help provide and enhance our service and tailor content. By continuing, you agree to the

Q RELX

use of cookies. 